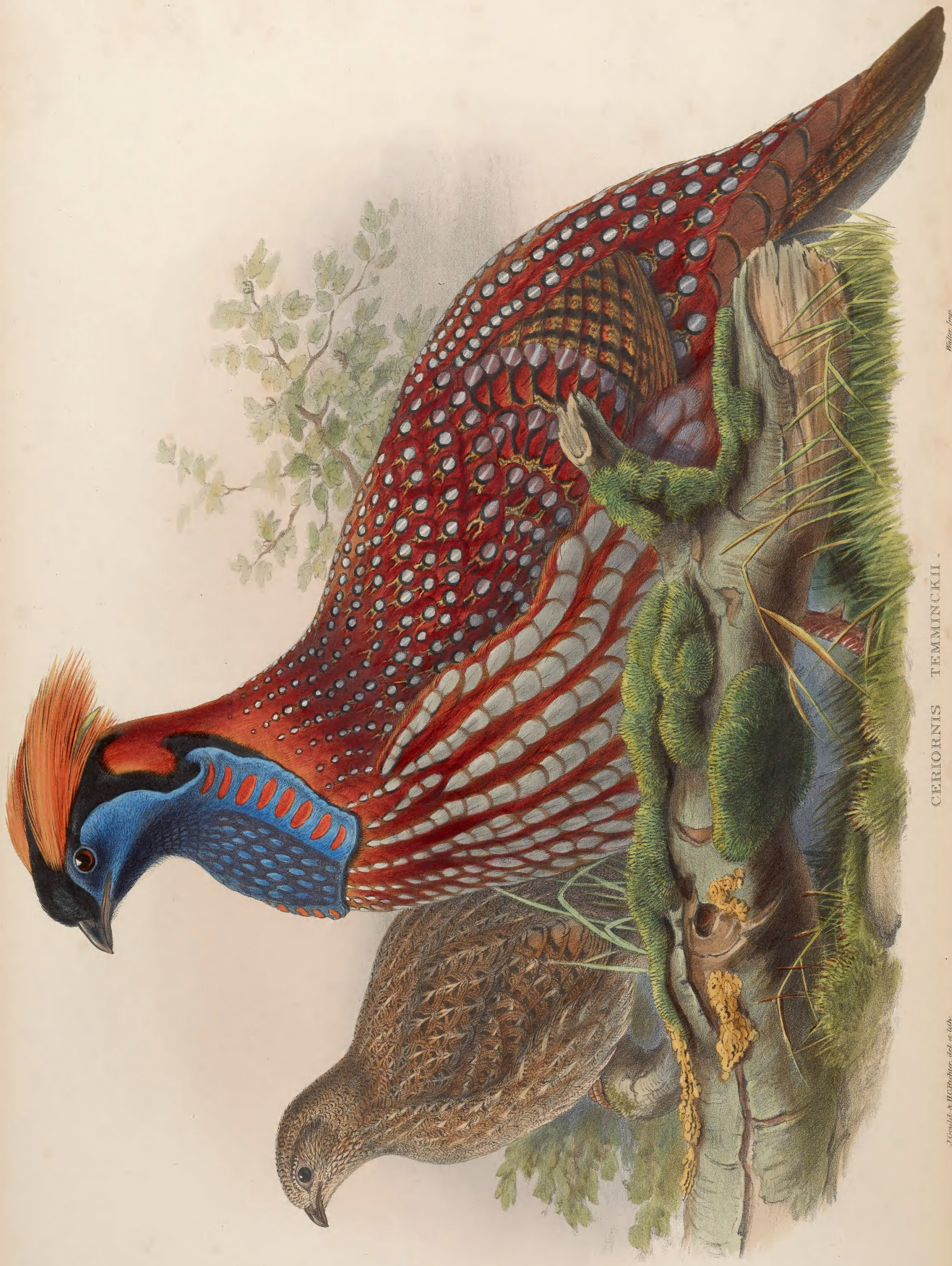




\title{
CERIORNIS TEMMINCKII.
}

\author{
Temminck's Horned Pheasant.
}

Satyra Temminckii, J. E. Gray in Hardw. Ill. Ind. Zool., vol. i. pl. 50.-Bonap. Compt. Rend. de l'Acad. Sci., tom. xlii. séance du 12 mai 1856

Tragopan 'Temminckii, Benn. in Proc. of Zool. Soc., part ii., 1834, p. 33.

Ceriornis Temminckii, G. R. Gray, Gen. of Birds, vol. iii. p. 499, Ceriornis sp. 3.-Gray, List of Spec. of Birds in Coll. Brit. Mus., part. v. Galline, p. 41.-Sclat. in-Proc. of Zool. Soc., 1863, p. 123.

Fon our first knowledge of the existence of this Chinese species of Ceriornis we are indebted, as in the case of the Phasianus Reevesii, to the gentleman after whom that bird was named. It is true that it formed one among the mañy grotesque objects represented in the rice-paper drawings which had for many years been sent to Europe, but which was supposed to be entirely imaginary, until living examples in the celebrated menagerie of the late Mr. Beale, at Macao, attracted the notice of Mr. Reeves, who did not rest until he had sent specimens to the national collection, and made us acquainted with a bird of which we had previously only seen faulty representations. Now (1868) living examples not only grace our menageries, but are breeding as freely as any species of a form differing essentially from every other comprising the avifauna of Europe can be expected to do: it is fortunate that such is the case; for ornithologists have thereby been enabled to study their varied actions and manners during the exciting period of spring, and to ascertain that they are both curious and interesting. Of the true habitat of this bird, which is probably the most eastern species of the genus, as the $C$. melanocephalus is the most western, our knowledge is extremely scanty; for all we know is that it is a native of China, probably the hills in continuation of the great Himalayas. On the southern slopes of these lofty ranges, but at a considerable elevation, all the four known species most likely dwell; two of them certainly reside there, namely the $C$. melanocephalus in the north-western provinces of Kumaon, at an elevation of 10,000 feet, and the $C$. satyra at a similar altitude in Nepaul, Bootan, and Sikhim ; but, as before mentioned, the habitat of the present species is unknown; and we are equally unacquainted with that of $C$. Caboti. Besides being indebted to Mr. Reeves for the first introduction of $\boldsymbol{C}$. Temminckï, science is under considerable obligation to Mr. James J. Stone for his perseverance in obtaining many of the living examples now in this country; and I have, moreover, to thank him for the loan of specimens of both sexes, whereby I am enabled to give a more faithful representation of them than I could otherwise have done. The accuracy of the accompanying plate has, moreover, been greatly aided by Mr. T. W. Wood's sketches of the form and colouring of the wattles of the male during the nuptial season. The displays of this appendage made by the bird at that time are most astonishing, and must be seen to be appreciated : so extraordinary are they, that the keepers in the Zoological Society's Gardens could not help expressing to me their surprise and wonder at its instant prolongation and contraction; "like a flash of lightning " was the simile of one, "like brilliant fireworks" that of another. These manifestations of excitement I have also witnessed myself ; and the sudden descent of the immense wattle of blue and red, the dilatation of the cylindrical pendent horns of verditer green and blue, and the depression of the feathers of the crown, and their lateral expansion over the eyes, afforded me much pleasure and delight. To figure these instantaneous exhibitions is impossible; and beautiful as the accompanying representation may appear, it falls far short of the original.

One of the earliest contributors to our knowledge of this bird is Dr. George Bennett, of Sydney, New South Wales, who, when in England in 1834, exhibited, at the meeting of the Zoological Society of London held on the 13th of May, specimens of three kinds of Ceriornes, including the present species, and, in illustration of its history, placed upon the table drawings of specimens observed by him at Macao, showing the remarkable wattle in various stages of expansion, and read the following note on the subject :-

"In its contracted state the membrane has merely the appearance of a purple skin under the lower mandible; and is even sometimes so much diminished in size as to be quite invisible. It becomes developed during the early spring months or pairing-season of the year, from January to March, when it is capable of being displayed or contracted at the will of the bird. During excitement it is enlarged, falls over the breast, and exhibits the most brilliant colours, principally of a vivid purple, with bright red and green spots, the colours varying in intensity according to the degree of excitement. When they are most brilliant (that is, when the excitement is great) the purple horns are usually elevated." The living specimens seen by $\mathbf{M r}$. Bennett were procured from the province of Yunnan, bordering on Thibet. Mr. Beale, in whose aviary at Macao they were, had not succeeded in obtaining females. Its Chinese name is Tu Xou Nieu. 
The specific distinctions of this bird, compared with the other members of the genus, are so well marked that they need not be dwelt upon; but I may mention that the grey centres of the abdominal feathers constitute the most conspicuous of them.

As is the case with all the other species, the sexes differ materially in colour.

The male has the lores, forehead, a few of the foremost feathers of the crest, a broad stripe over each eye, the ear-coverts, the sides of the head, occiput, and nape deep black; remainder of the crest, neck, and breast rich deep chestnut-red; all the upper surface is also chestnut-red in general appearance, but on examination each feather is found to be mottled with black and white, the latter assuming a $\mathrm{V}$-shaped form with the base towards the extremity; at the centre of the tip is a nearly round spot of white encircled by a narrow ring of black, on each side of which the tip is rich deep chestnut; primaries blackish brown, conspicuously mottled on the outer and minutely on the inner web with tawny or deep buff; feathers of the under surface of the body and the under tail-coverts grey, broadly margined with reddish chestnut, which, on the thighs, gradually becomes light red without any grey in the centre; lower part of the tail-coverts deep grey, gradually mingling with the dark dull red of their margins; tail mottled black, brown, and buff ; wattles rich blue, with, in the centre of each side, a series of short bands of scarlet; the undersides of the wattles are moreover sparsely clothed with black feathers, which, projecting beyond the edge, give them a fringed appearance; bill and feet horn-colour.

The female is mottled all over with brown, black, and buff, with a few white markings on the centres of the back-feathers, and of grey on those of the breast.

The accompanying plate represents a male nearly of the size of life, and a female considerably reduced. 


\section{$2 \mathrm{BHL}$ Biodiversity Heritage Library}

Gould, John. 1869. "Temminck's Horned Pheasany, Ceriornis temmincki [PI. 46]." The Birds of Asia 7(XXI), -. https://doi.org/10.5962/p.323292.

View This Item Online: https://www.biodiversitylibrary.org/item/122491

DOI: https://doi.org/10.5962/p.323292

Permalink: https://www.biodiversitylibrary.org/partpdf/323292

\section{Holding Institution}

Smithsonian Libraries

\section{Sponsored by}

Smithsonian Institution Libraries

\section{Copyright \& Reuse}

Copyright Status: Not in copyright

This document was created from content at the Biodiversity Heritage Library, the world's largest open access digital library for biodiversity literature and archives. Visit BHL at https://www.biodiversitylibrary.org. 